\title{
AN INDEXATION SYSTEM FOR ASSESSING EMERGING CHINESE BANK COMPETITIVENESS: THE CASE OF HUAXIA BANK
}

\author{
Long ZHANG ${ }^{1}$ - Steven SHWIFF² - Qun XU $^{3}$ \\ ${ }^{1}$ School of Humanities \& Economic Management, China University of Geosciences (Beijing), \\ Haidian District, Beijing, 100083. \\ E-mail: zhanglongdragon@hotmail.com (corresponding author) \\ ${ }^{2}$ Department of Economics/Finance, Texas A\&M University - Commerce, P.O.Box.3011 \\ Commerce, TX, USA.E-mail: Steven.Shwiff@tamuc.edu \\ ${ }^{3}$ School of Humanities \& Economic Management, China University of Geosciences (Beijing), \\ Haidian District, Beijing, 100083.E-mail:xuq@cugb.edu.cn
}

\begin{abstract}
A 2010 banking survey of 42 foreign bank executives by Price Waterhouse Coopers ranked competition from "domestic" Chinese banks as their primary concern. This outranked the "regulatory environment" which had been number one for the previous two years. Several reasons were cited by foreign bank managers but three stand out: (1) declining market share for foreign banks due to reduced number of multinationals doing business in China, (2) foreign banks reluctance to lend locally due to the global economic slowdown, (3) the aggressive lending strategies of Chinese banks. This paper focuses on the new reality of contemporary Chinese banking practice. We believe Chinese banks are learning and adapting. They are gaining expertise in a wide array of bank operations such as asset management, branching, securities, leasing and many more. To better understand the nature and context of growing Chinese bank competitiveness, we introduce and apply the concept financial "econiche". Financial econiche refers to the learning and adapting that takes place in a specific financial "ecological" surrounding with attention paid to the macroeconomic need for harmonious development. Econiche theory borrows heavily from similar ideas in the natural world. We construct an evaluation indexation system based on the econiche theory, and use Huaxia bank as a case study.
\end{abstract}

Keywords: bank competitiveness in a socialist economy, Chinese bank management, econiche theory, Chinese banking practice 


\section{INTRODUCTION}

Before 1978 China was a monobank system with the Peoples Bank of China (PBOC) playing both the roles of a central bank and a commercial bank. Since then, China has embarked upon some fundamental changes to its domestic banking system. Foreign banks have opened in China, the PBOC behaves more like a central bank only, and bank competition is on the rise (Zhang 2003). Newly formed domestic commercial banks are faced with business and managerial challenges like operational intelligence, business networking, branch virtualization, and organizational intensification ( $\mathrm{Wu} 2012$ ). Yet, banking remains a highly regulated market with strict cash and credit controls being imposed by the State Planning Commission. Policy lending still is a conduit used by the Communist Party to ensure achievement of national, regional and even local outcomes. So within this new market structure how to best judge the evolving or organic nature of the private bank market and steer policy reforms in a direction where competition and efficiency become key metrics for the new and growing class of joint-stock commercial banks.

A biological econiche refers to the spatial and intertemporal context in which any natural species finds itself (Huang 1994). Much like natural organisms, a business also occupies a spatial context similar to an ecological environment. Thus, business econiche refers to interconnections a business has formed as it interacts with other businesses, government, and the broader social culture. Just like natural organisms adopt symbiotic and competitive evolutionary strategies so must business.

We adapt this broader context of business econiche to help us understand and provide policy recommendations to the emerging joint-stock banking sector in China. We argue that while each bank occupies a contemporaneous econiche, it is evolving and changing over time. We use Huaxia Bank as a case study to demonstrate how econiche helps the bank to improve its efficiency and competitiveness thus contributing to national improved outcomes (Zhang and Guo 2009).

\section{LITERATURE REVIEW}

Ecological niche theory has a long academic history. Work by Grinell in 1917 referred to the interplay between vegetative cover, habitat, non-biological factors, resources, and prey. He further suggested that two species in the same spatial habitat wouldn't occupy the same econiche (Sun 1980). In 1957, Hutchinson expanded the ideas and proposed a multi-dimensional hyper-volume model. This model considers space, resource utility as well as other aspects. He argued that 
multiple resource factors in the environment impact biological success but that each factor must exceed a threshold level before impacting survivability. Species could only survive and multiply in those threshold exceeding areas. The combination of these points forms the multi-dimensional hyper-volume econiche for a species (Zhu 2006). The concept of multi-dimensional hyper-volume is at the core of modern econiche theory.

When species occupy the same space the resulting competition is called coenosis. When resources within the shared hyper-volume are insufficient to support existing species, competition is what results. This competition within an overlapping spatial proximity can lead to some species being driven from those overlapping spaces. However, if the econiche is large enough, there is no resulting competition. The econiche is stable. If such a stable econiche suffers damage or invasion, the species will respond with collaborative cooperation in order to survive and maintain the balance of the whole ecosystem ( $\mathrm{Li}$ and Lin 2010).

Econiche theory has been applied to business administration and management successfully (Hu, 2009). Similar to natural species, businesses exist in an ecological environment. This environment is formed by political, social, technological, economic, operational and international factors (Liu 2010). In the following sections we apply the concepts of econiche theory to the Chinese banking system. We then develop an indexation methodology based on econiche concepts and apply them to policy issues facing Huaxia Bank.

There remains, however, the issue of our choice of econiche theory over other traditional statistical methodologies. Our choice was based on the following considerations:

(1) The competitive portion of the Chinese banking industry is emergent and still dominated by government fiat. Thus, data may simply not be present with a sufficient enough number of observations nor in fact truly reflect the underlying economic dynamics they purport to represent. Therefore, we were confronted with significant questions of not only model specification but data robustness.

(2) Econiche theory allows for the integration of both quantitative and qualitative data. An integrative approach seems better suited to the management needs of this emergent sector. Policy recommendations flowing from such approaches are more likely to find favor than from abstract quantitative and or statistical models.

(3) It is our belief that parallels between biological adaptability and the current evolutionary status of the for-profit Chinese banking sector are too intuitively appealing to ignore. Therefore, we believe pursuing this line of research will provide new perspectives on banking evolution. 


\subsection{Principles of financial econiche theory}

The principles of financial econiche posit that for any given time, space and set of functional interrelationships for financial entities (banks in our paper) can be thought of as an ecosystem (Qian 2009). As with natural ecosystems we can imagine either a narrow or wide niche. A narrow financial econiche would imply fewer interconnections between banks therefore leading to less competition between banks operating in that niche. The opposite would also hold. If there are few interconnections between banks, then one would expect underutilized resources. In such a situation any bank wishing to expand its scope of operations will find resources available. If some banks wish to follow an expansion strategy, resource utilization will increasingly become more efficient. The dynamics between these two principles will result in increased competition within the banking niche. As in any expanding or competitive market, we would expect to see firms attempting to grow their market share, new firms would consider entry, and those firms less able to compete might leave the niche.

With this brief primer, let's consider in greater detail the dynamics of econiche theory by introducing a taxonomy which is based upon the concepts of width, density, and overlap (Zhu and Yang 2007).

\subsubsection{Financial econiche width}

Financial econiche width refers to the scale of bank operations. Bank scale economies are a key index for the competitiveness of a bank in the ecosystem. The breadth of product options, capital sufficiency and banking basics are key metrics (Zhang and Guo 2009). Wide econiche implies greater adaptive scale and scope. However, such growing scale also often results in decreasing efficiency and higher costs. Thus banks operating in a wide niche often tend towards the generalization and pluralism. Banks operating within a narrow niche enjoy limited adaptive scope propelling them towards specialization. The bank's niche determines its adaptive strategy. A large-scale bank has more choices and options but the scale of its operations imposes greater organizational inertia, and less flexibility. Such banks should adopt wide econiche model. Banks with small or medium scale should adopt a narrow econiche strategy. This would allow them to exert their special advantage by seeking a market (niche) position using specialized products or services. 


\subsubsection{Financial econiche density}

Financial econiche density refers to the number of banks and associated market shares within the niche. The less dense an econiche the fewer banks we would expect and each having a smaller market share. As a result there is less competition, lower risk of failure, and more opportunities to survive. Density offers corresponding advantages for those operating within that niche. New entrants may eye a less dense econiche rather than trying to enter a more dense market space. Small banks trying to compete in a wide niche are likely to fail (Zhang 2010).

\subsubsection{Financial econiche overlap}

Financial econiche overlap refers to the degree of homogeneity among bank products and operational strategies (Zhang and Guo 2009). Overlap also occurs when many banks are using the same environmental resources in the same ecosystem. First mover advantages for banks moving into new markets can be substantial. However, as overlap grows with new entrants, incumbents and new entrants compete for the same target customers, resources and dwindling pool of talent. This competition leads to shrinking market share for each bank and increases strategic rivalry. However banks can reduce the competitive impacts of overlap by introducing product differentiation and market positioning.

These indexes above have an influence on conduct and performance within any given financial econiche. Generally speaking, the width of the econiche, adaptive scale and density are directly to the intensity of competition among banks.

The density and the width of econiche together can be called the econiche intensity (Cang 2006). The differentiation degree of intensity and overlap resulted in three different results: the monopoly, occupancy, and co-prosperity of econiche. The econiche monopoly means some bank constructs the industrial barrier by its advantage to engross or form oligopoly situation. The competition of the banks in financial ecosystem will result in the changing of econiche, and the econiche occupancy is the inexorable trend for their survival and development.

\subsection{Competitive analysis}

As Chinese banks continue operating in a relatively more competitive environment, it is essential that they have a taxonomy which allows them to recognize and define competitors. Using financial econiche theory as a guide, two indexes 
focused on certain components of competition present themselves. They are (1) the competitive elements inherent in the overlap, and (2) competitive elements emanating from the intensity of a financial econiche.

\subsubsection{Elements of competitor recognition in regards to financial econiche overlap}

According to the econiche theory, it includes six elements: time, space, width, deepness, space quality and target market (Cang 2006; Tang 2007).

\subsubsection{Competitive elements of financial econiche intensity}

According to the econiche theory, it includes adaptive ability, survival ability, and evolutionary ability (Zhai 2005).

\section{METHODOLOGY}

\subsection{Design of evaluative indexation system for financial econiche intensity}

The goal of an evaluative indexation system is to assess the abilities of two or more banks to acquire needed resources when they exist within a financial econiche overlap market. Based on the concepts we have thus far proposed, we devise a banking indexation system consisting of three categories: (1) adaptive ability, (2) survival ability, and (3) evolutionary ability.

Our indexation system of financial econiche intensity includes both quantitative and qualitative indexes aggregated by use of weighting scheme. We have chosen an AHP (Analytic Hierarchy Process) method to ensure the validity, reliability and independence of the indexation system.

\subsection{Evaluative indexation system construction}

We constructed our evaluation indexation system based on three major level-one categories: Adaptive ability, Survival ability, and Evolutionary ability. We also used ten level-two categories, which were derived from the competitive elements of financial econiche intensity.

Further, we invited 12 senior managers from seven banks in China (one from Huaxia Bank, two from China Merchants Bank, two from Minsheng Bank, two 


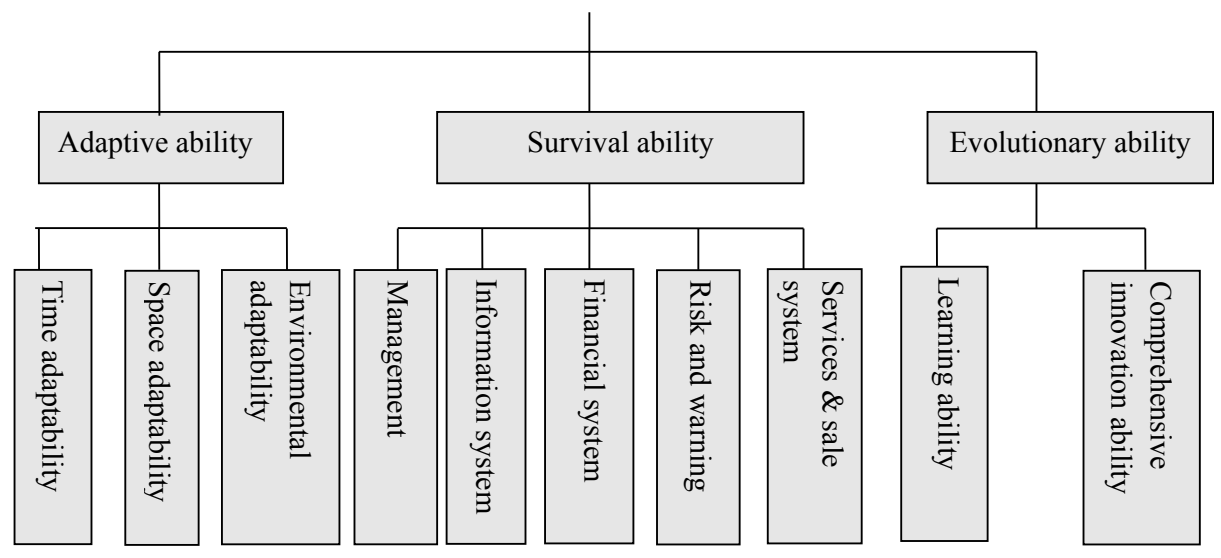

Figure 1. Diagram of evaluation indexation system of financial econiche intensity

from China Everbright Bank, two from Guangdong Development Bank, two from Shanghai Pudong Development Bank, and one from Industrial Bank) to a brainstorming focus group session. They were asked to list a third-level of indexes from the 10 level-two categories. Given our ability to collect data on the proposed level-three categories, we selected twenty-five out of those suggested by our focus group members.

The evaluation indexation system constructed includes 3 level-one categories, 10 level-two indexes and 25 detailed level-three indexes (see Figure 1 and Table 1).

\subsection{Competitor identification}

There are 11 national small-or medium-sized joint-stock commercial banks (China Merchants Bank, China CITIC Bank, China Minsheng Bank, Shanghai Pudong Development Bank, Industrial Bank, Shenzhen Development Bank, China Everbright Bank, Guangdong Development Bank, Zhejiang Business Bank, Prudential Bank, Bank of Bohai) whose business scopes and nature are close to our target bank - Huaxia Bank. Six of the eleven banks were too homogeneous in their operations to be of value (China Merchants Bank, China Minsheng Bank, China Everbright Bank, Guangdong Development Bank, Shanghai Pudong Development Bank, and Industrial Bank). That left six banks which were relatively differentiated banks from our target for our analysis after the assessment of the temporal element, space element, and target market element. 
Table 1. Detailed evaluation indexation system of financial econiche intensity

\begin{tabular}{|c|c|c|c|}
\hline $\begin{array}{l}\text { The index of } \\
\text { level } 1\end{array}$ & $\begin{array}{l}\text { The index } \\
\text { of level } 2\end{array}$ & The index of level 3 & $\begin{array}{c}\text { Data source, calculation formula } \\
\text { or index explanation }\end{array}$ \\
\hline \multirow{6}{*}{$\begin{array}{l}\text { Adaptive } \\
\text { ability }\end{array}$} & \multirow[b]{2}{*}{ Time adaptability } & Running period (year) & Operational period \\
\hline & & $\begin{array}{l}\text { Current stage in the } \\
\text { life cycle }\end{array}$ & $\begin{array}{l}\text { Including incubation, growth } \\
\text { maturity and recession period }\end{array}$ \\
\hline & \multirow{3}{*}{$\begin{array}{l}\text { Space } \\
\text { adaptablity }\end{array}$} & Market coverage & $\begin{array}{l}=\text { The number of regions covered by } \\
\text { target bank / the number of regions } \\
\text { covered by banking industry }\end{array}$ \\
\hline & & $\begin{array}{l}\text { Rate of newly added } \\
\text { branches }\end{array}$ & $\begin{array}{l}=\text { The number of newly added } \\
\text { branches this year / the total number } \\
\text { of branches last year }\end{array}$ \\
\hline & & $\begin{array}{l}\text { The function and status } \\
\text { of a bank in commer- } \\
\text { cial ecosystem }\end{array}$ & $\begin{array}{l}\text { Backbone, middle type, niche type } \\
\text { (see Classification Research by } \\
\text { Marco Lansiti and Ray Levien) }\end{array}$ \\
\hline & $\begin{array}{l}\text { Environment } \\
\text { adaptability }\end{array}$ & $\begin{array}{l}\text { Economic contribution } \\
\text { of a bank }\end{array}$ & $\begin{array}{l}\text { = sum of profit and tax of the bank / } \\
\text { the average sum of profit and tax } \\
\text { of local banks }\end{array}$ \\
\hline \multirow{10}{*}{$\begin{array}{l}\text { Survival } \\
\text { ability }\end{array}$} & \multirow{2}{*}{ Management } & Development strategy & $\begin{array}{l}\text { From Commercial Bank of China } \\
\text { Competitive Report (2009) - Table } \\
\text { of core competence evaluation } \\
\text { of national banks }\end{array}$ \\
\hline & & Corporate government & $\begin{array}{l}\text { From Commercial Bank of China } \\
\text { Competitive Report (2009) - Table } \\
\text { of core competence evaluation } \\
\text { of national banks }\end{array}$ \\
\hline & $\begin{array}{l}\text { Information } \\
\text { system }\end{array}$ & IT & $\begin{array}{l}\text { From Commercial Bank of China } \\
\text { Competitive Report (2009) - Table } \\
\text { of core competence evaluation } \\
\text { of national banks }\end{array}$ \\
\hline & \multirow{5}{*}{ Financial system } & \begin{tabular}{|l|}
$\begin{array}{l}\text { Rate of return on } \\
\text { equity }\end{array}$ \\
\end{tabular} & $=$ Net profit $/$ average total assets \\
\hline & & Asset-liability ratio & $=$ Total liability / total assets \\
\hline & & Liquidity ratio & $=$ Current assets / current liabilities \\
\hline & & Net profit growth rate & $\begin{array}{l}=\text { Net profit growth this year / net } \\
\text { profit last year }\end{array}$ \\
\hline & & Asset value-rate & $\begin{array}{l}=\text { Final total owners' equity / total } \\
\text { owners' equity at the beginning } \\
\text { of the period }\end{array}$ \\
\hline & \multirow[b]{2}{*}{$\begin{array}{l}\text { Services \& sale } \\
\text { system }\end{array}$} & $\begin{array}{l}\text { Ratio of fees and com- } \\
\text { missions out of income }\end{array}$ & $\begin{array}{l}=\text { Fee and commission income / } \\
\text { operating income }\end{array}$ \\
\hline & & Products and services & $\begin{array}{l}\text { From Commercial Bank of China } \\
\text { Competitive Report (2009) - Table } \\
\text { of core competence evaluation } \\
\text { of national banks }\end{array}$ \\
\hline
\end{tabular}


Table 1 continued

\begin{tabular}{|c|c|c|c|}
\hline $\begin{array}{l}\text { The index of } \\
\text { level } 1\end{array}$ & $\begin{array}{l}\text { The index } \\
\text { of level } 2\end{array}$ & The index of level 3 & $\begin{array}{c}\text { Data source, calculation formula } \\
\text { or index explanation }\end{array}$ \\
\hline \multirow{7}{*}{$\begin{array}{l}\text { Survival } \\
\text { ability }\end{array}$} & \multirow[t]{2}{*}{$\begin{array}{l}\text { Services \& sale } \\
\text { system }\end{array}$} & $\begin{array}{l}\text { Customer satisfaction } \\
\text { rate }\end{array}$ & $\begin{array}{l}\text { From Customer Satisfaction Study } \\
\text { on China Retail Bank in } 2010 \text { from } \\
\text { JD Power Asia Pacific (1000-point } \\
\text { scale) }\end{array}$ \\
\hline & & Sales growth rate & $\begin{array}{l}=\text { Gross sales of a bank this year / } \\
\text { gross sales of the bank last year }\end{array}$ \\
\hline & \multirow{5}{*}{ Risk and warning } & Capital adequacy rate & $\begin{array}{l}=(\text { Core capital }+ \text { subsidiary capital }) \\
/ \text { risk-weighted assets }\end{array}$ \\
\hline & & \begin{tabular}{|l|}
$\begin{array}{l}\text { Core capital adequacy } \\
\text { ratio }\end{array}$ \\
\end{tabular} & $=$ Core capital $/$ risk-weighted assets \\
\hline & & \begin{tabular}{|l|}
$\begin{array}{l}\text { Non-performing loans } \\
\text { ratio }\end{array}$ \\
\end{tabular} & $\begin{array}{l}=(\text { subprime loans }+ \text { doubtful loans }+ \\
\text { loss loans }) / \text { total loans }\end{array}$ \\
\hline & & \begin{tabular}{|l|}
$\begin{array}{l}\text { Provision coverage } \\
\text { ratio }\end{array}$ \\
\end{tabular} & $\begin{array}{l}\text { = Loan loss reserve balances / non- } \\
\text { performing loan balances }\end{array}$ \\
\hline & & Risk management & $\begin{array}{l}\text { From Commercial Bank of China } \\
\text { Competitive Report (2009) - Table } \\
\text { of core competence evaluation of } \\
\text { national banks }\end{array}$ \\
\hline \multirow[b]{2}{*}{$\begin{array}{l}\text { Evolutionary } \\
\text { ability }\end{array}$} & Learning ability & Training proportion & $\begin{array}{l}=\text { Training person-time / total } \\
\text { number of employees }\end{array}$ \\
\hline & $\begin{array}{l}\text { Comprehensive } \\
\text { innovation ability }\end{array}$ & Process bank & $\begin{array}{l}\text { From Commercial Bank of China } \\
\text { Competitive Report (2009) - Table } \\
\text { of core competence evaluation of } \\
\text { national banks }\end{array}$ \\
\hline
\end{tabular}

\subsection{Data collection and analysis}

We collected our data from the annual Chinese Commercial Bank Development Report (2009), the Chinese Commercial Bank Competitiveness Report (2008), the websites of the study banks, and the website of the China Banking Regulatory Commission. Table 2 details the data obtained.

China Merchants Bank, Minsheng Bank, Huaxia Bank, China Everbright Bank, Guangdong Development Bank, Shanghai Pudong Development Bank and Industrial bank are assigned to X1, X2, X3, X4, X5, X6 and X7. After brainstorm and expert ratings, data computation and related information ranking, we can get the weight for each index in financial econiche intensity evaluation system.

We then apply a Boolean fuzzy logic technique to convert the complex and interconnected relationships inherent in competitor analysis to come up with a single weighted index. Suppose that there are $m$ factors: (the 25 indexes in our case) and there are $n$ market competitors within the market: (the seven banks in our case). Each factor, then, can be arranged into a linear sequence according to some property, say, X. Further, the weight of each factor will be: 


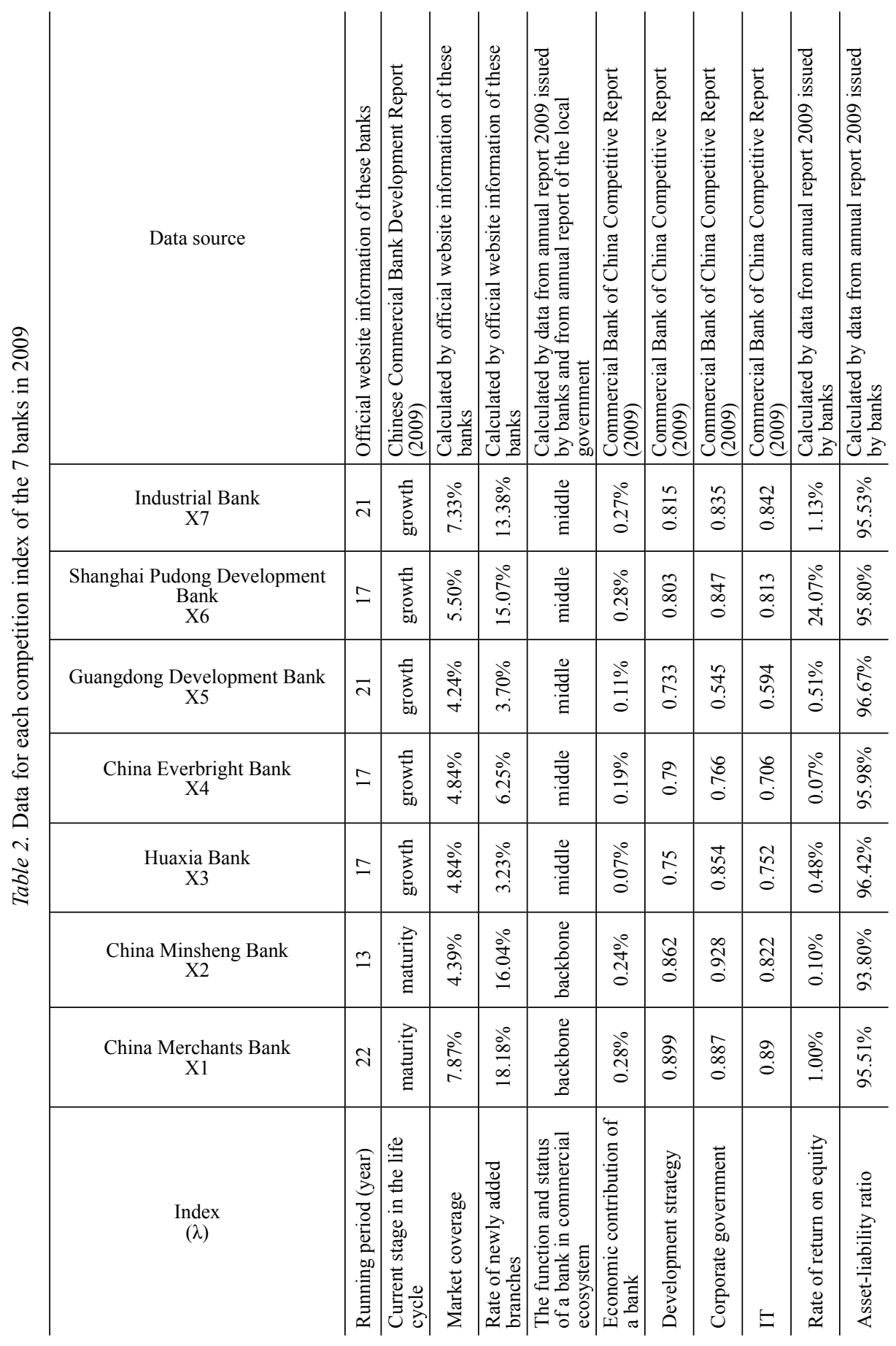




\begin{tabular}{|c|c|c|c|c|c|c|c|c|c|c|c|c|c|}
\hline 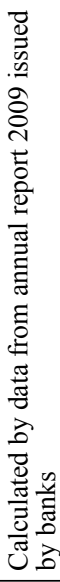 & 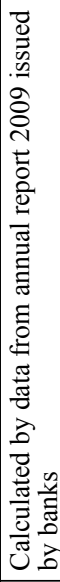 & 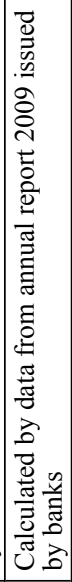 & 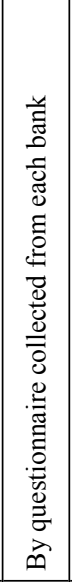 & 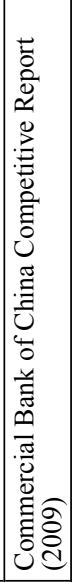 & 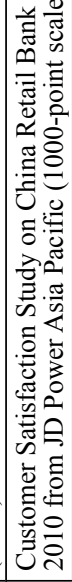 & 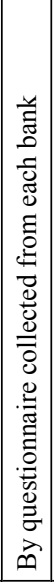 & 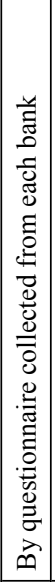 & 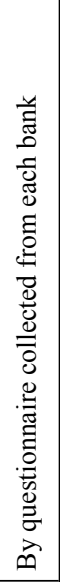 & 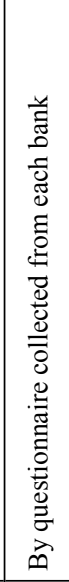 & 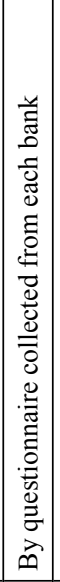 & 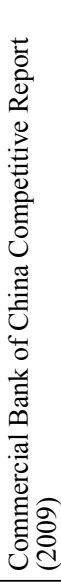 & 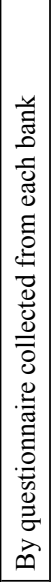 & 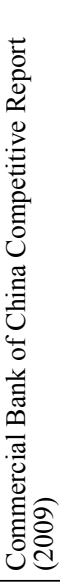 \\
\hline$\vec{n}$ & $\begin{array}{l}0 \\
\dot{0} \\
\stackrel{0}{0}\end{array}$ & $\begin{array}{l}\stackrel{0}{\circ} \\
i \\
\stackrel{-}{n}\end{array}$ & $\begin{array}{l}\stackrel{\circ}{\circ} \\
\stackrel{\circ}{\circ}\end{array}$ & $\stackrel{2}{\stackrel{0}{\circ}}$ & $\bar{\sim}$ & 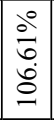 & $\begin{array}{c}\stackrel{0}{i} \\
\stackrel{2}{0} \\
0\end{array}$ & $\frac{\partial}{a}$ & $\begin{array}{l}\stackrel{\circ}{\circ} \\
\stackrel{2}{\circ}\end{array}$ & \begin{tabular}{|l|}
$\stackrel{0}{ }$ \\
$\grave{\alpha}$ \\
$\dot{\nu}$ \\
\end{tabular} & $\begin{array}{l} \pm \\
\infty \\
0 \\
0\end{array}$ & $\stackrel{n}{\stackrel{n}{0}}$ & $\begin{array}{c}n \\
\infty \\
0 \\
0\end{array}$ \\
\hline$\underset{i}{\stackrel{0}{ }}$ & $\begin{array}{l}\stackrel{0}{ } \\
\stackrel{n}{n} \\
\ddot{n}\end{array}$ & $\begin{array}{l}\stackrel{\circ}{\hat{N}} \\
\stackrel{3}{0}\end{array}$ & مे & $\begin{array}{l}\vec{\circ} \\
\infty \\
0\end{array}$ & $\underset{⿱}{\stackrel{D}{*}}$ & 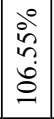 & 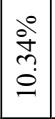 & $\begin{array}{l}\stackrel{\circ}{0} \\
\text { gे }\end{array}$ & $\begin{array}{l}\stackrel{0}{0} \\
\stackrel{\infty}{0} \\
\stackrel{0}{0}\end{array}$ & 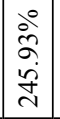 & $\begin{array}{l}\vec{b} \\
\infty \\
0\end{array}$ & \begin{tabular}{|l|}
$\infty$ \\
$\stackrel{-}{-}$ \\
\end{tabular} & $\begin{array}{l}m \\
\infty \\
0 \\
0\end{array}$ \\
\hline $\begin{array}{l}\infty \\
\infty \\
0\end{array}$ & $\begin{array}{l}\stackrel{0}{\circ} \\
\dot{\vec{d}}\end{array}$ & $\begin{array}{l}\stackrel{0}{0} \\
\text { ஸे } \\
\stackrel{\Xi}{=}\end{array}$ & $\underset{\substack{i \\
\infty}}{\stackrel{0}{\circ}}$ & $\stackrel{m}{\stackrel{m}{*}}$ & $\ddot{\infty}$ & $\begin{array}{c}0 \\
\dot{v} \\
m \\
i \\
\infty \\
\infty\end{array}$ & \begin{tabular}{|c|}
$\stackrel{0}{0}$ \\
$\infty$ \\
$\infty$ \\
$\infty$
\end{tabular} & $\begin{array}{l}\stackrel{0}{0} \\
\dot{i} \\
\dot{i}\end{array}$ & $\begin{array}{l}\stackrel{0}{\circ} \\
\stackrel{+}{+} \\
\text { i }\end{array}$ & 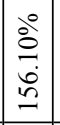 & oे & - & \begin{tabular}{l}
\multirow{0}{*}{} \\
ర్ \\
0
\end{tabular} \\
\hline$\stackrel{\oplus}{\rightarrow}$ & $\begin{array}{l}\stackrel{\circ}{+} \\
\stackrel{+}{+}\end{array}$ & $\begin{array}{l}\stackrel{0}{0} \\
\text { ¿े } \\
\dot{y}\end{array}$ & $\begin{array}{c}\stackrel{0}{0} \\
\dot{\infty}\end{array}$ & $\begin{array}{c}0 \\
⿱ 0 \\
\infty \\
0 \\
0\end{array}$ & $\underset{⿱}{\stackrel{\Delta}{*}}$ & 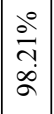 & 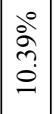 & $\begin{array}{l}\stackrel{0}{\circ} \\
\dot{+} \\
\dot{0} \\
\dot{0}\end{array}$ & ì & 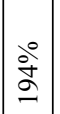 & $\begin{array}{l}\overrightarrow{2} \\
0\end{array}$ & $\begin{array}{l}0 \\
0 \\
0\end{array}$ & $\underset{⿱ 乛}{\stackrel{J}{0}}$ \\
\hline ô. & $\begin{array}{l}\stackrel{\circ}{~} \\
\stackrel{+}{i} \\
\text { ते }\end{array}$ & $\begin{array}{l}\stackrel{0}{0} \\
\stackrel{0}{0} \\
\stackrel{0}{0} \\
=\end{array}$ & $\begin{array}{l}\dot{0} \\
\dot{0} \\
\dot{r}\end{array}$ & $\begin{array}{c}\tilde{n} \\
\stackrel{0}{0}\end{array}$ & $\underset{0}{0}$ & $\mid \begin{array}{l}0 \\
\dot{0} \\
\stackrel{1}{a} \\
\hat{\sigma}\end{array}$ & $\mid \begin{array}{c}\stackrel{0}{0} \\
\stackrel{i}{0} \\
\stackrel{0}{0}\end{array}$ & $\begin{array}{l}\stackrel{0}{\circ} \\
\dot{+} \\
0 \\
\dot{0}\end{array}$ & $\begin{array}{l}\stackrel{0}{0} \\
\stackrel{n}{\rightarrow}\end{array}$ & 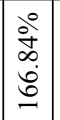 & $\begin{array}{l}\overrightarrow{\hat{\sigma}} \\
\hat{0}\end{array}$ & 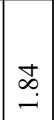 & $\begin{array}{l}\tilde{N} \\
0 \\
0 \\
0\end{array}$ \\
\hline ås & $\begin{array}{l}\stackrel{0}{ } \\
\stackrel{\circ}{+} \\
\stackrel{n}{ }\end{array}$ & $\begin{array}{l}\stackrel{0}{8} \\
\dot{8} \\
\text { ఠర }\end{array}$ & $\stackrel{\stackrel{8}{\circ}}{=}$ & $\stackrel{\hat{尺}}{\stackrel{0}{0}}$ & $\stackrel{\infty}{6}$ & 离 & $\begin{array}{l}\stackrel{0}{\circ} \\
\stackrel{\tilde{\sigma}}{0} \\
\stackrel{0}{0}\end{array}$ & $\begin{array}{l}\grave{\alpha} \\
\grave{\infty}\end{array}$ & $\begin{array}{l}0 \\
0 \\
\infty \\
0 \\
0\end{array}$ & 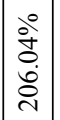 & $\begin{array}{c}= \\
\infty \\
0\end{array}$ & $\begin{array}{l}\hat{\infty} \\
i \\
i\end{array}$ & $\overline{\hat{\sigma}}$ \\
\hline $\begin{array}{l}\infty \\
\infty \\
0 \\
0\end{array}$ & $\begin{array}{l}\stackrel{0}{+} \\
\stackrel{+}{a} \\
\stackrel{\text { in }}{1}\end{array}$ & $\begin{array}{l}\stackrel{0}{8} \\
\stackrel{0}{0} \\
=\end{array}$ & 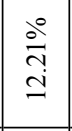 & $\frac{0}{\sigma}$ & $\stackrel{ \pm}{~}$ & 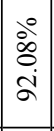 & $\begin{array}{c}0 \\
\stackrel{8}{0} \\
\stackrel{9}{0} \\
0\end{array}$ & $\begin{array}{l}0 \\
\hat{\delta} \\
0 \\
0\end{array}$ & $\begin{array}{c}0 \\
\grave{0} \\
\infty \\
0\end{array}$ & $\mid \begin{array}{l}0 \\
0 \\
0 \\
0 \\
0 \\
\dot{+} \\
\text { d }\end{array}$ & $\begin{array}{l}\infty \\
\stackrel{0}{0} \\
0 \\
0\end{array}$ & $\stackrel{n}{n}$ & $\bar{a}$ \\
\hline 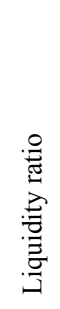 & 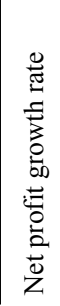 & 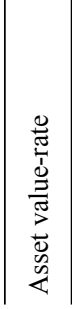 & 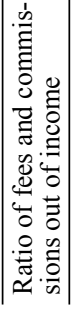 & 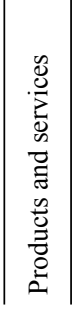 & 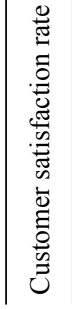 & 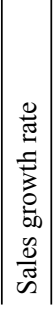 & 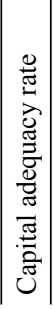 & 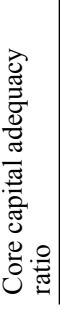 & 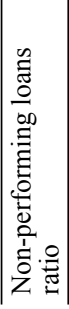 & 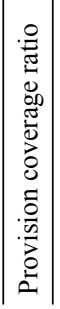 & 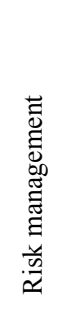 & 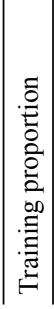 & 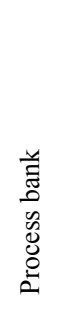 \\
\hline
\end{tabular}




$$
\delta_{m}=\left\{\delta_{1}, \delta_{2}, \ldots, \delta_{m}\right\}, \text { and } \Sigma_{k=1}^{m} \delta_{k}=1 .
$$

The weight of the $\mathrm{k}$-th factor $\lambda_{k}(k=1,2, \ldots, m)$ would be:

$$
\begin{aligned}
& U_{\lambda k}\left(x_{i}, x_{j}\right) \begin{cases}=0 & \text { if } x_{i} \text { is inferior to } x_{j} \\
=0.5 & \text { if } x_{i} \text { is equal to } x_{j} \\
=1 & \text { if } x_{1} \text { is superior to } x_{j}\end{cases} \\
& r_{i j}=\sum_{k=1}^{m} \delta_{k} \cdot U_{\lambda k}\left(x_{i}, x_{j}\right)
\end{aligned}
$$

Using Boolean methods we got the value of 0.5940 in Table 6, in this way, we can get all the vectors in Table 6 .

$$
(\mathrm{i}=1,2, \ldots, \mathrm{n} ; \mathrm{j}=1,2, \ldots, \mathrm{n})
$$

Then we create an $\mathrm{n} \times \mathrm{n}$ fuzzy relation matrix $R=\left(r_{i j}\right)_{n \times n}$. $\mathrm{R}$ is called the competition matrix, and it follows then that:

$$
\mathrm{r}_{i i}=0, \mathrm{r}_{i j}+\mathrm{r}_{j i}=1
$$

Finally, we can calculate the support vector $\alpha_{n}\left\{\alpha_{1}, \alpha_{2}, \ldots, \alpha_{n}\right\}$, and

$$
\alpha_{j}=\sum_{j=1}^{n} r_{i j}(i=1,2, \ldots, n)
$$

Comparing each element of the support vector and sorting them in descending order, we can ascertain the order of each element of $X$, and thus their scores or ranks. These scores are in fact the competition intensity order (Liu, Zhou and Li 2011).

From the data obtained in Table 4, we rank the seven banks for each index. If the two values are the same, we use an equals sign to indicate that result. After ranking for 25 indexes, we get the rank of each bank out of the 7 for each index (see Table 3).

We can get the competition matrix of financial econiche intensity (see Table 4) putting the data into mathematic formula (1) by Boolean method, which shows the competitiveness of the 7 banks. 
Table 3. Ranking and weight of each bank for each index of financial econiche intensity

\begin{tabular}{|c|c|c|c|c|c|c|c|c|}
\hline Index $(\lambda)$ & & & & $\operatorname{ank}(X$ & & & & Weight $(\delta)$ \\
\hline$\lambda_{1}$ Running period (year) & $\mathrm{X} 1$ & $\mathrm{X} 5$ & $=\mathrm{X} 7$ & $\mathrm{X} 3$ & $=\mathrm{X} 4$ & $=\mathrm{X} 6$ & $\mathrm{X} 2$ & $5.6 \%$ \\
\hline$\lambda_{2}$ Current stage in the life cycle & $\mathrm{X} 1$ & $=\mathrm{X} 2$ & $\mathrm{X} 3$ & $=\mathrm{X} 4$ & $=\mathrm{X} 5$ & $=\mathrm{X} 6$ & $=\mathrm{X} 7$ & $5.7 \%$ \\
\hline$\lambda_{3}$ Market coverage & $\mathrm{X} 1$ & $\mathrm{X7}$ & $\mathrm{X} 6$ & $\mathrm{X} 3$ & $=\mathrm{X} 4$ & $\mathrm{X} 2$ & $\mathrm{X} 5$ & $6.5 \%$ \\
\hline$\lambda_{4}$ Rate of newly added branches & $\mathrm{X} 1$ & $\mathrm{X} 2$ & $\mathrm{X} 6$ & $\mathrm{X} 7$ & $\mathrm{X} 4$ & $\mathrm{X} 5$ & $\mathrm{X} 3$ & $3.6 \%$ \\
\hline $\begin{array}{l}\lambda_{5} \text { The function and status of a bank in } \\
\text { commercial ecosystem }\end{array}$ & $\mathrm{X} 1$ & $=\mathrm{X} 2$ & $\mathrm{X} 3$ & $=\mathrm{X} 4$ & $=\mathrm{X} 5$ & $=\mathrm{X} 6$ & $=\mathrm{X} 7$ & $5.3 \%$ \\
\hline$\lambda_{6}$ Economic contribution of a bank & $\mathrm{X} 1$ & $=\mathrm{X} 6$ & $\mathrm{X7}$ & $\mathrm{X} 2$ & $\mathrm{X} 4$ & $\mathrm{X} 5$ & X3 & $2.3 \%$ \\
\hline$\lambda_{7}$ Development strategy & $\mathrm{X} 1$ & $\mathrm{X} 2$ & $\mathrm{X} 7$ & X6 & $\mathrm{X} 4$ & $\mathrm{X} 3$ & X5 & $1.7 \%$ \\
\hline$\lambda_{8}$ Corporate government & $\mathrm{X} 2$ & $\mathrm{X} 1$ & $\mathrm{X} 3$ & $\mathrm{X} 6$ & $\mathrm{X} 7$ & $\mathrm{X} 4$ & $\mathrm{X} 5$ & $5.6 \%$ \\
\hline$\lambda_{9} \mathrm{IT}$ & $\mathrm{X} 1$ & $\mathrm{X7}$ & $\mathrm{X} 2$ & $\mathrm{X} 6$ & $\mathrm{X} 3$ & $\mathrm{X} 4$ & $\mathrm{X5}$ & $4.4 \%$ \\
\hline$\lambda_{10}$ Rate of return on equity & X6 & $\mathrm{X7}$ & $\mathrm{X} 1$ & $\mathrm{X} 5$ & $\mathrm{X} 3$ & $\mathrm{X} 2$ & $\mathrm{X} 4$ & $6.1 \%$ \\
\hline$\lambda_{11}$ Asset-liability ratio & $\mathrm{X} 2$ & $\mathrm{X} 1$ & $\mathrm{X} 7$ & $\mathrm{X} 6$ & $\mathrm{X} 4$ & $\mathrm{X} 3$ & $\mathrm{X} 5$ & $2.4 \%$ \\
\hline$\lambda_{12}$ Liquidity ratio & X6 & $\mathrm{X} 2$ & $\mathrm{X} 7$ & $\mathrm{X} 4$ & $\mathrm{X} 3$ & $\mathrm{X} 1$ & $=\mathrm{X} 5$ & $6.3 \%$ \\
\hline$\lambda_{13}$ Net profit growth rate & $\mathrm{X} 2$ & $\mathrm{X} 3$ & $\mathrm{X} 5$ & $\mathrm{X} 7$ & $\mathrm{X} 6$ & $\mathrm{X} 4$ & $\mathrm{X} 1$ & $4.3 \%$ \\
\hline$\lambda_{14}$ Asset value-rate & X6 & $\mathrm{X} 2$ & $\mathrm{X} 4$ & $\mathrm{X} 7$ & $\mathrm{X} 1$ & $\mathrm{X} 5$ & $\mathrm{X} 3$ & $2.2 \%$ \\
\hline $\begin{array}{l}\lambda_{15} \text { Ratio of fees and commissions out } \\
\text { of income }\end{array}$ & $\mathrm{X} 1$ & $\mathrm{X} 2$ & $\mathrm{X} 7$ & $\mathrm{X} 5$ & $\mathrm{X} 4$ & X6 & $\mathrm{X} 3$ & $3.3 \%$ \\
\hline$\lambda_{16}$ Products and services & $\mathrm{X} 1$ & $\mathrm{X} 4$ & $\mathrm{X} 6$ & $\mathrm{X7}$ & $\mathrm{X} 2$ & $\mathrm{X} 3$ & $\mathrm{X5}$ & $2.1 \%$ \\
\hline$\lambda_{17}$ Customer satisfaction rate & $\mathrm{X} 1$ & $\mathrm{X} 7$ & $\mathrm{X} 4$ & $=\mathrm{X} 6$ & $\mathrm{X} 2$ & $\mathrm{X} 3$ & $\mathrm{X} 5$ & $1.7 \%$ \\
\hline$\lambda_{18}$ Sales growth rate & $\mathrm{X} 2$ & $\mathrm{X} 7$ & $\mathrm{X} 6$ & $\mathrm{X} 4$ & $\mathrm{X} 3$ & $\mathrm{X} 1$ & $\mathrm{X} 5$ & $2.6 \%$ \\
\hline$\lambda_{19}$ Capital adequacy rate & $\mathrm{X} 7$ & $\mathrm{X} 1$ & $\mathrm{X} 6$ & $\mathrm{X} 4$ & $\mathrm{X} 3$ & $\mathrm{X} 2$ & $\mathrm{X} 5$ & $2.8 \%$ \\
\hline$\lambda_{20}$ Core capital adequacy ratio & $\mathrm{X} 2$ & $\mathrm{X} 7$ & $\mathrm{X} 6$ & $\mathrm{X} 3$ & $=\mathrm{X} 4$ & $\mathrm{X} 1$ & $\mathrm{X} 5$ & $6.2 \%$ \\
\hline$\lambda_{21}$ Non-performing loans ratio & $\mathrm{X} 7$ & $\mathrm{X} 2$ & $=\mathrm{X} 6$ & $\mathrm{X} 1$ & $\mathrm{X} 4$ & $\mathrm{X} 3$ & $\mathrm{X} 5$ & $2.1 \%$ \\
\hline$\lambda_{22}$ Provision coverage ratio & $\mathrm{X} 7$ & $\mathrm{X} 1$ & $\mathrm{X} 6$ & $\mathrm{X} 2$ & $\mathrm{X} 4$ & $\mathrm{X} 3$ & $\mathrm{X} 5$ & $2.8 \%$ \\
\hline$\lambda_{23}$ Risk management & $\mathrm{X} 1$ & $\mathrm{X} 6$ & $\mathrm{X7}$ & $\mathrm{X} 2$ & $\mathrm{X} 3$ & $\mathrm{X} 4$ & $\mathrm{X} 5$ & $5.8 \%$ \\
\hline$\lambda_{24}$ Training proportion & $\mathrm{X} 1$ & $\mathrm{X} 2$ & $\mathrm{X} 3$ & $\mathrm{X} 6$ & $\mathrm{X} 5$ & $\mathrm{X} 4$ & $\mathrm{X} 7$ & $5.2 \%$ \\
\hline$\lambda_{25}$ Process bank & $\mathrm{X} 2$ & $\mathrm{X} 1$ & $\mathrm{X} 7$ & $\mathrm{X} 3$ & $\mathrm{X} 6$ & $\mathrm{X} 4$ & $\mathrm{X} 5$ & $3.4 \%$ \\
\hline
\end{tabular}

Table 4. Competition matrix of financial econiche intensity for the 7 banks

\begin{tabular}{c|c|c|c|c|c|c|c|c}
\hline & $\mathrm{X} 1$ & $\mathrm{X} 2$ & $\mathrm{X} 3$ & $\mathrm{X} 4$ & $\mathrm{X} 5$ & $\mathrm{X} 6$ & $\mathrm{X} 7$ & Result \\
\hline $\mathrm{X} 1$ & 0.0000 & 0.5940 & 0.8060 & 0.7840 & 0.9255 & 0.6905 & 0.6460 & 4.4460 \\
\hline $\mathrm{X} 2$ & 0.4060 & 0.0000 & 0.7900 & 0.8130 & 0.8830 & 0.5475 & 0.5780 & 4.0175 \\
\hline $\mathrm{X} 3$ & 0.1940 & 0.2100 & 0.0000 & 0.4945 & 0.7140 & 0.2680 & 0.2060 & 2.0865 \\
\hline $\mathrm{X} 4$ & 0.2160 & 0.1870 & 0.5055 & 0.0000 & 0.7000 & 0.1455 & 0.1500 & 1.9040 \\
\hline $\mathrm{X} 5$ & 0,7450 & 0.1170 & 0.2860 & 0.3000 & 0.0000 & 0.1870 & 0.1780 & 1.0680 \\
\hline $\mathrm{X} 6$ & 0.3095 & 0.4525 & 0.7320 & 0.8545 & 0.8130 & 0.0000 & 0.4470 & 3.6085 \\
\hline $\mathrm{X} 7$ & 0.3540 & 0.4220 & 0.7940 & 0.8500 & 0.8220 & 0.5530 & 0.0000 & 3.7950 \\
\hline
\end{tabular}




\section{RESULTS}

Using formula (2), we can obtain a single value for each bank's support vector:

China Merchants Bank $=4.4460$,

China Minsheng Bank $=4.0175$,

Huaxia Bank $=2.0865$,

China Everbright Bank $=1.9040$,

Guangdong Development Bank $=1.0680$,

Shanghai Pudong Development Bank $=3.6085$

Industrial Bank $=3.7950$.

It is clear that China Merchants Bank occupies the dominant market position of the seven banks we have examined. Further, the bank that occupies the most similar financial econiche as Huaxia Bank is China Everbright Bank, though Huaxia may be the stronger competitor of the two.

Using an absolute score difference of less than 2 between two banks as a competitor definition, then Huaxia Bank overlaps within the same niche as China Everbright Bank (0.1825), Guangdong Development Bank (1.0185), Shanghai Pudong Development Bank (-1.5220) and Industrial Bank (-1.7085). Moreover, Shanghai Pudong Development and Industrial Bank offer competitive strategies Huaxia may wish to emulate as they grow their market position.

\section{CONCLUSION}

As the Chinese banking system moves into a more competitive environment, banks will need all the tools they can muster to understand the nature of this new market environment. We believe that our indexation system using econiche concepts will offer Chinese bank management a tool to better understand who their true competitors are and more importantly to identify those banks whose strategies lead to higher profits and a healthier banking system.

\section{ACKNOWLEDGEMENT}

Supported by the Fundamental Research Funds for the Central Universities. 


\section{REFERENCES}

Cang, W. (2006). Translated from 'Study on Identification of Competitors and Competitive Tactics Based on Business Niche Theory'. Tongji University, China's CNKI Excellent Postgraduate Dissertation Full-Text Database, 18, 21-24, 24-30, 40-41.

Hao, G. and Li, D. (2012). Translated from 'Study on Measuring and Comparing the Sustainable Development of China's Listed Commercial Banks'. Journal of Northeastern University (Edition of Social Science), 14(1), 24-27.

Hu, W. (2009). Translated from 'Bionics and Business Management'. China Petrochem, 16, 26.

Huang, Y. (1994). Translated from 'Mathematical Methods in Niche Theory Study'. Chinese Journal of Applied Ecology, 5(3), 331.

Li, N. and Lin, Q. (2010). Translated from 'Study on Niche Theory and its Application'. The South of China Today, 11, 231.

Lin, K. and Guo, Y. (2010). Translated from 'The Research Advances on Niche Theory and its Application'. Journal of Fujian College of Forestry, 21(3), 284.

Liu, Z. (2010). Translated from 'Business Econiche Optimization Theory: Basic Connotation, Effect Factors and Strategies'. Journal of Yanshan University (Philosophy and Social Science Edition), 3, 140-143.

Liu, P. Zhou, X. and Li, S. (2011). Translated from 'Rational Conditions and Its Application of Blin Method in Group Decision Making'. Journal of Wenzhou University (Natural Sciences), 32(1), $17-22$.

Niu, R. (2009). Translated from 'Improvements of China's Rural Finance Ecology System'. Henan University, China's CNKI Excellent Postgraduate Dissertation Full-Text Database, 17.

Qian, X. (2009). Translated from On the Origin of Species written by Charles Robert Darwin in 1859. Chongqing Publishing Houses, 27.

Sun, R. (1980). Translated from Theoretical Ecology written by Robert May. Higher Education Press, 118-119.

Tang, R. (2007). Translated from 'Research of TPL Competitive Tactics Based on Enterprise Niche Theory'. Southwest University of Finance and Economics, China's CNKI Excellent Postgraduate Dissertation Full-Text Database, 16-19.

Wang, Y. (2007). Translated from 'A Theoretical and Empirical Study on Urban Competitive Based on Niche Theory'. Shanxi University of Finance and Economics, China's CNKI Excellent Postgraduate Dissertation Full-Text Database, 33.

Wu, W. (2012). Translated from 'Study on Reformation Development Path of China's Commercial Banks during "The Twelfth Five-year” Planning'. Financial Accounting, 1, 16-18.

Yan, A. (2007). Translated from 'Research on Construction of Evaluation Indexes and Model of Organization Niche'. Science \& Technology Progress and Policy, 24(7), 156.

Yang, Z. and Li, X. (2012). Translated from 'Study on Business Evolution from the Perspective of Biological Evolution'. Enterprise Management, 3, 18.

Zhang, C. (2010). Translated from 'Research on Enterprise Growth Based on the Niche Theory'. Jiangxi University of Finance and Economics, China's CNKI Excellent Postgraduate Dissertation Full-Text Database, 7-8.

Zhang, L. and Guo, Y. (2009). Translated from 'An Empirical Research on Banks' Ecological Niche in China'. Financial Theory \& Practice, 9, 13-14.

Zhang, Y. (2003). Translated from 'Comment on Jobless Recovery of American Economics'. News Report, 12, 45.

Zhu, Z. and Yang, S. (2007). Translated from 'The Development Strategy Based on the Econiche Theory'. Ecological Economy, 1, 288.

Zhu, Z. (2006). Translated from 'Econiche and Features of the Econiche of Regional Economic Organizations'. Social Sciences Journal of College of Shanxi, 18(1), 32. 